\section{Inheritance of Resistance to Squash Mosaic Virus in a Squash Transformed with the Coat Protein Gene of Pathotype 1}

\author{
R. Provvidenti ${ }^{1}$ \\ Cornell University, Department of Plant Pathology, New York State Agricultural \\ Experiment Station, Geneva, NY 14456-0462 \\ David M. Tricoli ${ }^{2}$ \\ Seminis Vegetable Seeds, Woodland, CA 95695 \\ Additional index words. cucurbits, coat protein, resistance, genetics, Cucurbita pepo
}

\begin{abstract}
In a yellow summer squash (Cucurbita pepo L.) experimental line developed by Seminis Vegetable Seeds, the coat protein gene of an American strain of squash mosaic virus (SqMV-M88), conferred resistance to Arizona, California, New Jersey, and New York strains belonging to the two pathotypes of the virus. An analysis of genetic populations derived from crosses and reciprocal backcrosses of a homozygous SqMV-resistant line A127-1-2 with the susceptible cultivar Butterbar revealed that the high level of resistance mimics the response of a single recessive gene.
\end{abstract}

Squash mosaic virus (SqMV) is one of the major viruses affecting Cucurbitaceae. It is seed-transmitted, and in nature, it is spread by striped and spotted cucumber beetles (Acalymna and Diabrotica sp.), hence it may occur wherever cucurbits are growing in the world (Campbell, 1971). Strains of SqMV have been classified in two pathogroups: Pathotype I, which usually causes prominent symptoms on melons and mild to moderate on squashes; and Pathotype II, which incites prominent symptoms on squashes and mild to moderate on melons. These two pathotypes can cause a variety of leaf symptoms, including prominent green veinbanding, mosaic, ringspots, and particularly, a protrusion of veins at the foliar margin. Under certain environmental conditions, infected plants of Cucurbita moschata and C. pepo may develop prominent foliar enations (Nelson and Knuhtesen, 1973).

Considering that SqMV can significantly reduce the quantity and the quality of cultivated cucurbits, our efforts have been directed, through the years, to find sources of resistance and introduce them into cultivars growing in the United States and other countries of the world. With very few exceptions, most of the germplasm tested was found to be susceptible to several strains of both pathotypes of the virus (Provvidenti, 1993). A very high level of resistance was found in all the lines of bottle gourd (Lagenaria siceraria) (Provvidenti, 1981), but attempts to cross this species with any of the Cucurbita species were without

Received for publication 23 Aug. 2000. Accepted for publication 8 May 2001.

${ }^{1}$ Plant Pathologist. To whom reprint requests should be addressed. Phone: 315 787-2316. E-mail address: rp13@cornell.edu.

${ }^{2}$ Research Scientist. success. A certain tolerance was located in wild squashes, Cucurbita ecuadorensis, $C$. martinezii, and C. okeechobeensis (Provvidenti et al., 1978), but difficulties were encountered in transferring it into cultivated squashes. However, considering the economic importance of this virus in squashes and the absence of a high level of resistance, the concept of pathogen-derived resistance (PDR) (Beachy et al., 1990; Grumet, 1990), can be exploited for the control of this seed-borne virus.

The genome of SqMV consists of two single-stranded positive-sense RNA molecules: a middle component (M-RNA) of $\approx 4200$ nucleotides and a bottom component (B-RNA) of $\approx 6000$ nucleotides. Both components are polyadenylated at the 3 ' end and possess a genome-linked protein ( $\mathrm{VPg}$ ) at the 5 ' termini. The M-RNA encodes the $42 \mathrm{kDa}$ and $22 \mathrm{kDa}$ coat proteins (CPs) and the cell-tocell movement proteins (Franssen et al., 1982; Hiebert and Purcifull, 1981; Wellink and van Kammen, 1989). The cDNA nucleotide sequence of these genes and their expression in plant cells was reported by $\mathrm{Hu}$ et al. (1993).

Using polymerase chain reaction (PCR) these genes were amplified and cloned in the sense orientation into a plant expression vector pUC18cpexp (Slightom, 1991). The resulting pUC18cpxp-22kDa and $-42 \mathrm{kDa} \mathrm{CP}$ plasmid were partially digested by Hind III and both SqMV $22 \mathrm{kDa}$ and $42 \mathrm{kDa} \mathrm{CP}$ expression cassettes were cloned by Pang et al (2000) into the transformation vector pGA482G, a derivative of pGA482 (An, 1987). The original binary vector pGA482 contains the right and left T-DNA borders of pTiT37, which flank the plant expressible neomycin phosphotransferase II gene (nptII), restriction enzyme polylinker, and bacteriophage lamda cos site. To improve the use of this vector, the bacterial gentamicin-(3)- $N$-acetyl- transferase gene (Allmansberger et al., 1985) was cloned into the $\mathrm{Sal}$ I site located outside the T-DNA region, generating pGA482G. The plant expressible SqMV CP transgenes were inserted as tandem repeats and were oriented in the same direction as the nptII gene. The resulting binary vector was transferred into a disarmed T-DNA deletion derivative of the Agrobacterium tumefaciens strain C58 (Pang et al., 2000). Squash inbred lines were transformed using a modification of the procedure of Horsch et al. (1985). The transformed status of plants was verified by rooting in vitro shoots on kanamycin, enzyme-linked immunosorbent assay (ELISA) for the linked nptII gene and Southern blot analysis for the SqMV coat protein genes. Here, we are reporting the inheritance of resistance to SqMV in a yellow summer squash (C. pepo) possessing CP genes of this virus.

\section{Materials and Methods}

A number of transgenic yellow crookneck squash lines were developed for resistance to SqMV by Seminis Vegetable Seeds, Oxnard Calif. using the CP genes of SqMV-M88, a melon strain of Pathotype $\mathrm{I}$. The $\mathrm{R}_{0}$ plant was initially backcrossed to its nontransgenic counterpart. A limited number of $\mathrm{R}_{1}$ progeny were inoculated. Plants exhibiting a recovery phenotype were self-pollinated. The $\mathrm{R}_{2}$ progeny was inoculated and a few plants of the line A127 remained free of symptoms and were self-pollinated to generate the $\mathrm{R}_{3}$ generation. $\mathrm{R}_{3}$ progeny were confirmed to be homozygous resistant. $\mathrm{R}_{3}$ plants of a promising line, A1271-2, were crossed with those of the SqMVsusceptible yellow type cultivar Butterbar. Plants of $F_{1}$ (A127-1-2 x 'Butterbar'), $F_{2}$ (A127-1-2x 'Butterbar'), and reciprocal backcross populations (A127-1-2 X 'Butterbar') $\mathrm{x}$ A127-1-2 and (A127-1-2 x 'Butterbar') $x$ 'Butterbar' were used for inheritance studies. All the plants, including parents, were mechanically inoculated first on the expanded cotyledons, and $5 \mathrm{~d}$ later, on each first leaf. This dual inoculation eliminated escapes, since $100 \%$ of the susceptible controls were infected. The SqMV-M88 culture was maintained in Seneca Zucchini and inocula consisted of 15 fold-diluted leaf extracts in $0.05 \mathrm{M}$ $\mathrm{K}_{2} \mathrm{HPO}_{4}(\mathrm{pH} 8.5)$ buffer. Resistance was confirmed by ELISA, using antiserum to SqMVM88. When ELISAs were inconclusive, recovery tests were made using zucchini plants as systemic hosts. All plants were grown in sterilized clay pots ( $550 \mathrm{~mL}$ volume) containing the Cornell artificial mix (spagnum peat, Whittemore vermiculite, Baker's dolomitic limestone and $\mathrm{N}-\mathrm{P}-\mathrm{K}$ ). (Agway, Syracuse, N.Y.) and treated with ENSTAR II $\{(\mathrm{S}-$ Kinoprene [2-propynyl (2E,4E)-(7S)-3,7,11trimethyl-2-4-dodecadienoate] $\}$ manufactured by Sandoz, Des Plaines, Ill. This insecticide was used for the control of whiteflies, aphids, armored scales, and mealybugs, and kept plants completely free of viral vectors. All the plants were grown in a restricted area of the greenhouse and during the winter months, natural light was supplemented with fluores- 
cent lights for $16 \mathrm{~h}$ daily. The greenhouse temperature ranged from 25 to $30^{\circ} \mathrm{C}$, with a relative humidity (RH) of $40 \%$ to $60 \%$.

\section{Results and Discussion}

Correlation between the presence of the squash coat protein gene and resistance was established by tracking the linked selectable markers gene, neomycin phosphotransferase (nptII) using NPTII ELISA kit (5 Prime to 3 Prime, Boulder, Colo.) in the $\mathrm{R}_{1}$ and $\mathrm{R}_{2}$ generation. Once homozygous lines were established only random tracking of the transgene was conducted in the backcrossed progeny.

Southern blots showed that A127 contained two transgene inserts, which segregated independently (Jan et al., 2000). However the independent inserts were not tracked in subsequent generations. $\mathrm{R}_{1}$ plants, which were identified as containing the linked nptII gene, exhibited a recovery phenotype whereas nontransgenic progeny were susceptible to the virus (Table 1 ). NPTII ELISAs on $\mathrm{R}_{2}$ progeny produced by self-pollinating plants with the recovery phenotype, gave a $3: 1$ ratio of positive to negative plants. All of the NPTII negative plants were susceptible to SqMV, whereas the NPTII positive lines displayed three phenotypes, resistant, recovery and susceptible. The ratio of NPTII positive resistant progeny, to NPTII positive susceptible or recovery progeny, to NPTII negative and susceptible progeny were consistent with a 1:2:1 Mendelian segregation ratio (Table 2). The resistant $R_{2}$ plants were self pollinated to produce the $R_{3}$ homozygous line A127-1-2.

$\mathrm{R}_{3}$ Plants of the resistant parent, A127-1-2, inoculated with SqMV-M88 reacted with local chlorotic spots, but the virus failed to move systemically. Plants of the other parent, 'Butterbar', reacted with prominent systemic mosaic, foliar serration, scattered enations, and plant stunting. All plants of $F_{1}$ (A127-1-2 $X$ 'Butterbar') were systemically infected, and the persistent symptoms closely resembled those of the susceptible parent. Two $\mathrm{F}_{2}$ families of (A127-1-2 X 'Butterbar') segregated in a ratio of 3 susceptible : 1 systemically resistant. Plants of the backcross population involving the resistant parent (A127-1-2 $x$ 'Butterbar') x A127-1-2 segregated in a ratio of 1 susceptible : 1 systemically resistant. Plants of the backcross population involving the susceptible parent (A127-1-2x 'Butterbar') $x$ 'Butterbar' were systemically infected. Thus, from the data presented in Table 3, it is evident that the resistance to SqMV-M88 in line A1271-2 behaved phenotypically as the expression of a single recessive gene.

To ensure that the gene was still present in the backcrossed populations tissue samples were harvested from a subset of the plants and assayed for the presence of the linked selectable marker gene, neomycin phosphotransferase (nptII) using NPTII ELISA kit (5 Prime to 3 Prime, Boulder, Colo.). All of the backcrossed lines expressed NPTII, indicating that the transgene was present. (Table 4). Although Southern blots were not performed on advanced generations, the segregation ra-
Table 1. Correlation between resistance and the presence of the SqMVcoat protein gene, 10, 25, and $35 \mathrm{~d}$ postinoculation (DPI) with SqMVM88 strain. The coat protein gene was tracked using enzyme-linked immunosorbent assay for the linked $n p t I I$ gene.

\begin{tabular}{lccccc}
\hline \hline & & & \multicolumn{2}{c}{ Resistance } & Disease \\
\cline { 4 - 5 } Line & NPTII & DPI & Fraction & Percent & severity \\
\hline 127 & Positive & 10 & 0 of 4 & 0 & 3.5 \\
& Negative & & 0 of 6 & 0 & 4.7 \\
& Positive & 25 & 3 of 4 & 75 & 5 \\
& Negative & & 0 of 6 & 0 & $0.2^{z}$ \\
& Positive & 35 & 4 of 4 & 100 & 0 \\
& Negative & & 0 of 6 & 0 & $5^{z}$ \\
\hline
\end{tabular}

${ }^{\mathrm{z}}$ Evaluation on new growth.

A scale of 0 to 9 , where $0=$ nonsymptomatic, and $9=$ severe systemic symptom.

Table 2. Correlation between resistance and the presence of the SqMV-coat protein gene in $\mathrm{T}_{2}$ progeny (backcrossed then self pollinated) tracked using the linked selectable marker gene nptII, $10 \mathrm{~d}$ postinoculation.

\begin{tabular}{lccccc}
\hline $\begin{array}{l}\text { \# of plants } \\
\text { observed }\end{array}$ & $\begin{array}{c}\text { No. of plants } \\
\text { expected }(1: 2: 1)\end{array}$ & NPTII & $\begin{array}{c}\text { Resistance } \\
(\%)\end{array}$ & $\begin{array}{c}\text { Avg } \\
\text { symptom rating }\end{array}$ & $\chi^{2}$ \\
\hline 7 & 7 & Positive & 100 & 0 & 0.04 \\
16 & $14^{z}$ & Positive & 0 & 4.1 & 0.16 \\
5 & 7 & Negative & 0 & 4.6 & 0.32 \\
\hline
\end{tabular}

${ }^{{ }^{2} \text { Eight of the } 14 \text { plants recovered from symptoms } 56 \mathrm{~d} \text { post inoculation with reduced or no symptoms }}$ on newly developed leaves. tios suggest that the two independent inserts, present in the $\mathrm{R}_{0}$ plant, segregated away from one another during the initial backcross to generate the $\mathrm{R}_{1}$ population, and that the single plant chosen for advancement contained only one of the two original inserts. The NPTII segregation ratios for the $R_{2}$ progeny are consistent with this hypothesis (Table 2).

As was mentioned previously, the resistance to SqMV in line A127-1-2 had derived from the CP of a strain belonging to Pathotype I (SqMV-M88). This strain had been originally isolated from melons growing in a field of Cornell Univ., Ithaca, N.Y. Additional tests, using 80 plants of A127-1-2 clearly demonstrated that they were resistant ing to Pathotype I (SqMV-CA35, -FL22, NY9, -NJ3, WI 66) and three to Pathotype II (SqMV-NY81, -PA66, -WA5). These strains were available from previous studies and had been collected in New York and New Jersey, to eight other strains of the virus; five belong- or obtained from cucurbit researchers of Arizona and California (Provvidenti and Robinson, 1974; Provvidenti et al., 1978; Provvidenti, 1998).

For the first time, a high level of resistance to SqMV is available for a major cucurbit crop, summer squash. Presently, this transgene for resistance to SqMV is confined to experimental lines possessing good horticultural characteristics, hence it can be effectively incorporated into commercial cultivars using a combination of pedigree and backcross breeding methods.

Previously, most of the CP genes conferring resistance to viruses in squashes were demonstrated to be monogenic dominant, and thus easily exploitable for the production of commercial $F_{1}$ hybrids (Tricoli et al, 1995). However, the resistance in the transgenic squash line A127-1-2 was found to be functionally fully recessive in conferring an effective resistance to strains of the virus belonging
Table 3. Inheritance of resistance to squash mosaic virus in a transgenic squash line (Cucurbita pepo L.) possessing the coat protein genes of SqMV-M88.

\begin{tabular}{|c|c|c|c|c|}
\hline \multirow[b]{2}{*}{ Parents and cross progeny } & \multicolumn{2}{|c|}{ No. of plants } & \multirow{2}{*}{$\begin{array}{c}\text { Expected } \\
\text { ratio (R:S) }\end{array}$} & \multirow{2}{*}{$\begin{array}{c}\text { Goodness } \\
\text { of fit }\end{array}$} \\
\hline & Resistant & Susceptible & & \\
\hline A127-1-2 & 35 & 0 & & \\
\hline Butterbar ${ }^{y}$ & 0 & 47 & & \\
\hline F1 (A127-1-2 x Butterbar) & 0 & 25 & & \\
\hline F2 (A127-1-2 x Butterbar) (1) & 38 & 105 & $1: 3$ & 0.67 \\
\hline F2 (A127-1-2 x Butterbar) (2) & 35 & 124 & $1: 3$ & 0.40 \\
\hline BC (A127-1-2 x Butterbar) x A127-1-2 & 40 & 47 & $1: 1$ & 0.47 \\
\hline BC (A127-1-2 x Butterbar) x Butterbar & 0 & 116 & & \\
\hline
\end{tabular}

Resistant.

${ }^{\mathrm{y}}$ Susceptible.

Table 4. NPT ELISA on progeny of across between transgenic line A127 and 'Butterbar'.

\begin{tabular}{lcccccccc}
\hline & \multicolumn{7}{c}{ Optical density } \\
\cline { 2 - 10 } Cross & 1 & 2 & 3 & 4 & 5 & 6 & 7 & 8 \\
\hline $127-1-2 \times$ Butterbar & 1.38 & 1.544 & 1.437 & 1.419 & 1.53 & 1.304 & 1.549 & 1.566 \\
\hline
\end{tabular}

Positive control $=1.650$; negative control $=0.032$. 
to pathotypes of SqMV. Therefore, commercial $F_{1}$ hybrids must be produced by crosses between two homozygous resistant transgenic parents. The virus is able to infect inoculated cotyledons or leaves, but fails to move systemically.

\section{Literature Cited}

Allmansberger R., B. Braun, and W. Piepersberg. 1985. Genes for gentamicin-(3)- $N$-acetyl-transferases III and IV. II. Nucleotide sequences of three AAC(3)-III genes and evolutionary aspect. Mol. Gen. Genet. 198:514-520.

An, G. 1987. Binary Ti vectors for plant transformation and promoter analysis. Meth. Enzymol. 153:292-305.

Beachy, R.N., S. Loesh-Fries, and N.E. Tumer. 1990 Coat protein-mediated resistance against virus infection. Annu. Rev. Phytopathol. 28:451-474.

Campbell, R.N. 1971. Squash mosaic virus. Description of plant viruses no. 43. C.M.I./A.A. M., Kew, Surrey, U.K.

Franssen, H., R. Goldbach, M.M. Brockhuijsen, and A. van Kammen. 1982. Expression of middlecomponent RNA of cowpea mosaic virus, in vitro generation of a precursor to both capsid proteins by bottom-component RNA encoded protease from infected cells. J. Virol. 41:8-17.

Grumet, R. 1990. Genetically engineered plant virus resistance. HortScience 25:508-513.

Hiebert, E., and D.E. Purcifull. 1981. Mapping of two coat protein genes on the middle RNA component of squash mosaic virus (Comovirus Group). Virology 113:630-636.

Horsch, R.B., J.E. Fry, N.L. Hoffmann, D. Eicholts, S.G. Rogers, and R.T. Fraley. 1985. A simple and general method for transferring genes into plants. Science 227:1229-1231.

Hu, J.S., S-Z. Pang, P.G. Nagpala, D.R. Siemieniak, J.L. Slightom, and D. Gonsalves. 1993. The coat protein genes of squash mosaic virus: Cloning, sequence analysis, and expression in tobacco protoplasts. Arch. Virol. 130:17-31.

Jan, F-J., Pang, S-Z., D.M. Tricoli, and D. Gonsalves. 2000. Evidence that plant development stage and combining transgenes from different lines enhance resistance in squash mosaic comovirus coat protein transgenic plants. J. General Virol. 81:2299-2306.

Nelson, M.R. and H.K. Knuhtsen. 1973. Squash mosaic virus variability: Review and serological comparisons of six biotypes. Phytopathology 63:920-926.

Pang, S-Z., F.-J. Jan, D.M. Tricoli, P.F. Russell, K.J. Carney, J.S. Hu, M. Fuchs, H.D. Quemada, and D. Gonsalves. 2000. Resistance to squash mosaic comovirus in transgenic squash plants expressing its coat protein genes. Mol. Breeding 6:87-93.

Provvidenti, R. 1981. Sources of resistance to viruses in Lagenaria siceraria. Cucurbit Genet. Coop. 4:38-40.

Provvidenti, R. 1993. Resistance to viral diseases of cucurbits, p. 8-43. In: MM. Kyle (ed.). Resistance to viral diseases of vegetables: Genetics and breeding. Timber Press, Portland, Ore.

Provvidenti, R. 1998. A source of a high level of tolerance to squash mosaic virus in a melon from China. Cucurbit Genet. Coop. Rpt. 21:29-30.

Provvidenti, R. and D. Gonsalves. 1995. Inheritance of resistance to cucumber mosaic virus in a transgenic tomato line expressing the coat protein gene of the white leaf strain. J. Hered. 86:85-88.

Provvidenti, R. and R.W. Robinson. 1974. Resistance to squash mosaic virus and watermelon mosaic virus 1 in Cucumis metuliferus. Plant Dis. Rpt. 58:735-738.

Provvidenti, R., R.W. Robinson, and H.M. Munger. 1978. Resistance in feral species to six viruses infecting Cucurbita. Plant Dis. Rpt. 62:326329.

Slightom, J.L. 1991. Custom polymerase-chainreaction engineering of a plant expression vector. Gene 100:251-255.

Tricoli, D.M., K.S. Carney, P.F. Russell, J.R. McMaster, D.W. Groff, K.C. Hadden, P.T. Himmel, J.P. Hubbard, M.L. Bueshore, and H.D. Quemada. 1995. Field evaluation of transgenic squash containing single or multiple coat protein constructs for resistance to cucumber mosaic virus, watermelon mosaic virus, and zucchini yellow mosaic virus. Bio/Technol. 13:1458-1465.

Wellink, J. and A. van Kammen. 1989. Cell-to-cell transport of cowpea mosaic virus requires both the $558 \mathrm{k} / 48 \mathrm{k}$ proteins and the capsid protein. J. General Virol. 70:2279-2286. 